\title{
IMPACT OF TILE DRAINAGE SYSTEM AND WATER QUALITY ON SOME SOIL PROPERTIES AND CROP YIELDS OF WHEAT AND MAIZE
}

\author{
Mona K.M. Abdul-Razek, M. Abd-Eladl and H.A. Khafagy \\ Soil, water and Environment Res. Inst., Agric. Res. Center (ARC).Giza, Egypt.
}

Received: Sep. 4, 2018

Accepted: Oct. 15, 2018

\begin{abstract}
The current study was carried out in two successive seasons (winter 2015/2016 and summer 2016) on two areas (Mahallet Rooh and Saft Torab). Both areas belong to El-Santa District (about $13 \mathrm{~km}$ to Tanta, Gharbia Governorate, Egypt). This work was conducted in clay loam soils to study the feasibility of installing tile drainage at farm level and using fresh and mixed water (fresh and drainage water i.e.1:1) on some soil properties, wheat and maize productivity. Moreover, the obtained field data were used to evaluate the field drains through comparing the calculated drain spacing using Hooghoud equation with the actual drain spacing.
\end{abstract}

Both areas have a covered drainage system. The laterals were constructed at $1.2 \mathrm{~m}$ depth and $30 \mathrm{~m}$ drain spacing with a length varies from 250-275 $\mathrm{m}$. Five feddans in each area were selected to carry out this study. Moreover, non- tiled drained areas were selected in both two areas as control areas.

The results of irrigation water analysis revealed that generally, both fresh and mixed water applied in this study could be used safely according to the standard guidelines of FAO (1994) which means that, using such mixed water safely can save about $50 \%$ of fresh water needed for crop water requirements. Also the results proved that, at Mahallet Rooh area where fresh irrigation water is used, the soil salinity reduced by about $30.7 \%$ as compared with the initial value in the area not provided with tile drainage, but the reduction in soil salinity was about $58.9 \%$ in the area provided with tile drainage system. The total amounts of leached salts from the top $60 \mathrm{~cm}$ of soil were 1850.4 and $2051.8 \mathrm{~kg} / \mathrm{fed}$ for non- tiled and tiled areas of Mahllet Rooh area, respectively. Concerning Saft Torab area, where mixed water is used for irrigation, these amounts were 1222.1 and $1965.2 \mathrm{~kg} / \mathrm{fed}$ for the top $60 \mathrm{~cm}$ of soil, respectively. The obtained results confirmed that, the tiled areas at Mahallet Rooh, where fresh irrigation water is applied, showed a relatively higher values of quickly drainable pores (QDP), slowly drainable pores (SDP) and consequently, the total drainable pores (TDP) as compared with that of Saft Torab area where mixed water is used for irrigation. On contrary, the water holding pores (I.e. fine and coarse capillary pores values) were relatively higher as compared with that of Mahallet Rooh area. The non-tiled areas in both Mahallet Rooh and Saft Torab showed almost the same values of pore size distribution components, but the fine capillary pores value (FCP) was slightly higher for Saft Torab as compared with that obtained for Mahallet Rooh area.

The results showed that soil bulk density values were lower in areas provided with tile drainage either in Mahallet Rooh or Saft Torab area resulting higher total porosity values as compared with that not provided with tile drainage. The results indicate that water table levels during winter season were much deeper than that observed in summer season in both areas under this study. The tile drainage areas showed a pronounced effect on lowering water table level as compared with the areas that not provided with tile drainage system. The results indicate that using mixed irrigation water which has a relatively higher salt content caused a higher salinity of water table as compared with that of Mahallet Rooh area where fresh irrigation water is used. 
Mona K.M. Abdul-Razek, et al.,

Drain spacing is calculated according to Hooghoudt equation using the field data measurements of soil hydraulic conductivity and water table levels midway between drains. The results revealed that, using the field data the calculated drain spacing was 27 $\mathrm{m}$ at Mahallet Rooh area, while it was to $30 \mathrm{~m}$ spacing at Saft Torab. The designed values were $30 \mathrm{~m}$ which is almost the same as the calculated values. These results indicate to the good performance of tile drains in both areas under the study according to the field actual measurements.

The results revealed that, both grain and biological wheat and maize yields in drained areas and that irrigated with fresh water are higher than that obtained in non-drained areas and that irrigated with mixed water.

Key words: Irrigation water quality, tile drainage, mixed water, leached salts, wheat yield

\section{INTRODUCTION}

One of the major problems confronting irrigated agriculture, nowadays throughout the world is the decreasing availability of fresh water. In many countries and regions, fresh water is relatively scarce, but there are considerable resources of saline water, which could be utilized for irrigation if proper crops, soil and water management practices were established (Mantell et al., 1985; Rhoades et al., 1992; Jessica, 2014).

In Egypt, less fresh water is available for agriculture with increasing population and rapid economic growth, and saline water has been included as an important substitutable resource for fresh water in agricultural irrigation. The safe and efficient use of saline water for irrigation is to undertake appropriate practices to prevent the development of excessive soil salinization for crop production. Many factors should be considered in making management strategies, such as crops, crop cultivars, local climate, soil texture type of salt, salinity levels, irrigation method and water management practices (Ferreyra et al., 1997; Shannon and Grieve, 1999; Bustan et al., 2004; Genxiang et al., 2017). Shalhevet (1994) and Minhas (1996) indicated that applying non-saline water in sensitive stages of plant growth and saline water in relatively tolerant stages could minimize the reduction in yield by salinity. So, the growth stage at which salinization is initiated must be taken into account. Due to the decreasing availability of fresh water to agriculture in many regions, saline water utilization in irrigation gets more and more attention. In order to facilitate the safe use of saline water for irrigation, the effects of salinity on crops should be understood, and optimal management strategies should be developed. (Wan, et al, 2007).

The increasing demand for water resources in the world, especially in the arid and semi-arid regions, has forced farmers to use low quality water for irrigation, such as agricultural drainage water and marginal quality ground water. Irrigation with these low quality water during the whole growing season of the crops, even the tolerant ones, does not always produce high yield. Mixing agricultural drainage water as well as low quality ground water with good quality water in ratios to keep the salinity of the irrigation water below the threshold of the target crop is an acceptable practice and is used by many scientists (Pasternak et al., 1986; Suarez and Lebron, 1993; Oster, 1994; Abdel Gawad and Ghaibeh, 2001; Hamidereza et al., 2018). Alternating good quality water with drainage (saline water) ; Increasing the salt tolerance of crops through plant breeding could increase the sustainability of irrigation with low quality water by reducing the need for leaching and allowing the use of poorer quality water is another management practice. Its 
application is easier because it does not need reservoirs for mixing two sources of irrigation water. Moreover, some scientists, in practicing the alternating management, used the good quality water during the sensitive stages of plant growth and the poor quality river during the non-sensitive stages (Chanduvi, 1997; Pasternak and De Malach, 1993; Rhoades, 1997).

Use of poor quality waters requires three changes from standard irrigation practices: ( 1 ) selection of appropriately salt-tolerant crops; (2) improvements in water management, and in some cases, the adoption of advanced irrigation technology; and (3) maintenance of soilphysical properties to assure soil tilth and adequate soil permeability to meet crop water and leaching requirement, (Phogat et al., 2018).

Increasing salts in the soil, as a result of irrigate with saline water, led to decreasing the water uptake by growing plants. If its damage effects continued along the duration of the crop growth without facing, it will extend the damage to the crop output quantitatively and qualitatively (Abou El-Defan et al, 2016). The key to salinity control and to irrigation sustainability is leaching (i.e. net downward movement of soil water and salt through the root zone). The net downward movement of both water and salt controls salt accumulation in the soil generates drainage water and influences drainage requirements and drainage water quality. The greater the salinity of the irrigation water, the greater the leaching, or drainage, required to maintain salinity in the soil at levels which are not toxic to crops. (Xiaobin, 2018).

One implication of the increased need for leaching as the salinity of the irrigation water increases is that soil-physical properties, must be maintained, and in some instances improved, so that the additional water required for leaching will infiltrate and move through the soil. Since the increased levels of salinity in municipal wastewaters and agricultural drainage waters are usually associated with increased levels of sodium, there is also a need to be aware of the sodicity hazards associated with water infiltration, hydraulic conductivity, and soil tilth (Qadir et al, 2007). The aim of this investigation is to evaluate the drain performance and also to study the effect of tile drainage system and irrigation water quality on some soil properties and wheat crop yield.

\section{MATERIALS AND METHODS}

\section{Experimental field location}

The current study was carried out in two successive seasons (winter 2015/2016 and summer 2016) on two areas (Mahallet Rooh and Saft Torab). Both areas belong to El-Santa District (about 13 km to Tanta, Gharbia Governorate, Egypt). The coordinates of the areas is approximately $30^{\circ} 52^{\prime} \mathrm{N} 3107 \mathrm{E}$. The total area of Mahallet Rooh is approximately 3000 feddans (1260 hectare). The soil texture of both areas was clay loam. Fresh irrigation water was taken from Mahallet Rooh Canal. On the other hand, the total area of Saft Torab is approximately 2000 feddans (840 hectare). Mixed irrigation water was taken from Meet Yazeed Canal and Saft Torab open drain (ratio of mixing 1:1). Both areas have a covered drainage system. The laterals were constructed at $1.2 \mathrm{~m}$ depth and $\mathbf{3 0} \mathrm{m}$ drain spacing with a length varies from $\mathbf{2 5 0 - 2 7 5} \mathrm{m}$. Five feddans (2.1 hectare) in each area were selected to carry out this study. Moreover, non-tiled drained areas were selected in both areas as control areas. The major cultivated crops in both areas are wheat in winter and maize and rice in summer.

\section{Chemical and physical characteristics of the soil and irrigation water}


Soil samples, which either were taken at depths of $0-30,30-60,60-90$ and $90-120$ $\mathrm{cm}$, air dried, crushed, sieved through a 2 $\mathrm{mm}$ sieve and then kept to subjected to the different soil analyses. The samples were subjected to determine some chemical and physical properties (Table 1):

- Soil reaction $(\mathrm{pH})$ in a 1:2.5 soil to water suspension and for irrigation water was measured using Becman's pH-meter, The electrical conductivity $\left(E C_{e}\right)$ values of the soil samples were measured in soil paste extract and in irrigation water using the electrical conductivity - meter, Soluble cations and anions in soil and irrigation water according to Jackson, (1967) and page et al. (1982).

- Sodium adsorption ratio (SAR) value is estimated according to (USSL, 1954).

- Adjusted Sodium adsorption ratio (Adj.SAR) value is estimated and Theoretical $\mathrm{pH}$ of irrigation water $\left(\mathrm{pH}_{\mathrm{c}}\right)$ is calculated according to Ayers and Wescot (1976).

- Residual Sodium Carbonate (RSC) = $\left(\mathrm{CO}_{3}{ }^{-+}+\mathrm{HCO}_{3}{ }^{-}\right)-\left(\mathrm{Ca}^{++}+\mathrm{Mg}^{++}\right)$according to (Eaton, 1950).

- Saturation Index (SI) $=\mathrm{pH}_{\mathrm{a}}-\mathrm{pH}_{\mathrm{c}}$ according to Wilcox (1966).

- Permeability index (PI \%) (PI \% $=\left\{\left(\mathrm{Na}^{+}+\right.\right.$ $\left.\left.\sqrt{\mathrm{HCO3}}) \div\left(\mathrm{Ca}^{++}+\mathrm{Mg}^{++}+\mathrm{Na}^{+}\right)\right\}^{*} 100\right)$ according to Doneen (1964).

- $\mathrm{Mg}$ Adsorption Ratio $=(\mathrm{Mg}) /(\mathrm{Ca}+\mathrm{Mg})$ where ions expressed as meq. $\mathrm{I}^{-1}$ according to FAO (1994).

- Particle size distribution was carried out by the international pipette method, Soil bulk density and Soil organic matter according to the standard methods described by Richard's (1954) and Klute (1986).

Table (1): Some physical and chemical characteristics of the soil under investigation.

1-Soil chemical analysis

\section{Mahallet Rooh}

(Fresh water)

8.6
- Pore size distribution was calculated according to De Leenheer and De Boodr (1965).

- The hydraulic conductivity was determined by the Auger Hole Method (Van Beers, 1976).

- As for the hydrological measurements, a set of observation wells has been installed midway between the laterals and also in the middle of the nondrained plots to determine water table level according to the method described by (Dieleman and Trafford, 1976).

\section{Drain spacing evaluation according to actual field measurements \\ Drain spacing is calculated using} Hooghoudt's fourmula (Hooghoudt, 1940), as follows:

$L^{2}=\left(8 K d h+4 K h^{2}\right) / q$

Where:

$$
\begin{aligned}
& \mathrm{L}=\text { drain spacing }(\mathrm{m}) \\
& \mathrm{K}=\text { hydraulic conductivity (m/day) } \\
& \mathrm{d}=\text { equivalent depth }(\mathrm{m}) \\
& \mathrm{h}=\text { hydraulic head }(\mathrm{m}) \\
& \mathrm{q}=\text { drain discharge rate (m/day) }
\end{aligned}
$$

\section{Wheat and maize yields}

The wheat and maize yields were determined and straw samples were dried, grounded and wet digested (Thomas et al., 1967).

\section{RESULTS AND DISCUSSION \\ 1. Irrigation water evaluation criteria \\ Data of irrigation water analysis} applied in this study is presented in Table (2). On the other hand, to evaluate the irrigation water used in this study some parameters were estimated and presented in Table (3). pH
Saft Torab

(Mixed water) 


$$
\mathrm{EC}_{\mathrm{e}}(\mathrm{dS} / \mathrm{m})
$$

- Soluble cations (meq/l)

$\mathrm{Ca}^{++}$

$\mathrm{Na}^{+}$

$\mathrm{K}^{+}$

- Souble anions (meq/l)
4.6

8.3

4.7

31.4

1.2

0.0

0.6

7.5

37.5
5.3

10.5

6.3

36.0

1.0

0.0

0.7

7.5

45.6

2-Soil physical properties

Organic matter \%

Bulk density $\left(\mathrm{gm} / \mathrm{cm}^{3}\right)$

Sat.K (m/day)

-Particle size distribution (\%)

Coarse sand \%

Fine sand \%

silt\%

Clay \%

Texture class

- Field Capacity (\%)

- Wilting point (\%)
0.8

1.35

0.08

5.6

17.9

38.5

38.0

clay loam

$37.6 \%$

$23.3 \%$
0.9

1.35

0.09

5.6

17.4

39.0

38.0

clay loam

$37.7 \%$

$23.3 \%$

Table (2): Chemical analysis of irrigation water applied in the study.

\section{Mahallet Rooh \\ (Fresh water)}

$\mathrm{EC}_{\text {iw }}(\mathrm{dS} / \mathrm{m})$

$\mathrm{pH}$

- Soluble cations (meq/l)

$\mathrm{Ca}^{++}$
$\mathrm{Mg}^{++}$
$\mathrm{Na}^{+}$
$\mathrm{K}^{+}$

$\mathrm{Ca}^{++}$

$\mathrm{K}^{+}$

Souble anions (meq/l)

$\begin{array}{lcc}\mathrm{CO}_{3}^{-} & 0.0 & 0.0 \\ \mathrm{HCO}_{3}^{--} & 0.4 & 0.5 \\ \mathrm{SO}_{4}^{--} & 1.3 & 1.5 \\ \mathrm{Cl}^{-} & 2.3 & 11.0\end{array}$

Table (3): Irrigation water quality criteria used in water quality evaluation
Saft Torab (Mixed water)

1.3

7.85

$1.0 \quad 3.5$

$0.8-1.1$

1.9

\section{Mahallet Rooh}

(Fresh water )

1- Salinity Hazard
Saft Torab

(Mixed water)

$$
\text { ECiw ( dS/m) }
$$

0.4

1.3 
Mona K.M. Abdul-Razek, et al.,

2- Sodicity Hazard

\begin{tabular}{|c|c|c|}
\hline a- SAR & 2.0 & 4.95 \\
\hline b- Adj.SAR & 5.41 & 5.69 \\
\hline $\mathrm{pH}_{\mathrm{c}}$ & 7.8 & 8.25 \\
\hline
\end{tabular}

3- Alkalinity Hazard

$\begin{array}{lll}\text { RSC } & -0.8 & -4.1\end{array}$

4- Permeability and Infiltration rate

Permeability Index (PI) $\quad 53 \% \quad 58 \%$

5- Toxity Hazard

$\begin{array}{lll}\mathrm{Cl}(\mathrm{meq} / \mathrm{l}) & 2.3 & 11.0 \\ \mathrm{SO} 4(\mathrm{meq} / \mathrm{l}) & 1.3 & 1.5 \\ \text { Boron (ppm) } & 0.1 & 0.2 \\ \text { Potential Salinity (PS } & 2.95 & 11.75\end{array}$

The results of irrigation water analysis (Table 2) and criteria used for evaluation of irrigation water (Table 3) revealed that both fresh and mixed water applied in this study can be used safely according to the standard guidelines of FAO (1994) which means that, using such mixed water safely can save about $50 \%$ of fresh water needed for crop requirements.

\section{Effect of irrigation water quality and drainage on soil salinity and leached salts \\ The effect of using fresh and mixed} irrigation water in areas with and without tile drainage system on soil salinity is studied. At Mahallet Rooh area where fresh irrigation water is used, the soil salinity in saturated extract expressed as ECe $(\mathrm{dS} / \mathrm{m})$ reduced from 3.9 (control salinity) to $2.7(\mathrm{dS} / \mathrm{m})$ which represents about $30.7 \%$ as compared to the initial value in the area not provided with tile drainage, but the reduction in soil salinity was about $58.9 \%$ in the area provided with tile drainage system. On the other hand, soil salinity at Saft Torab area where mixed water is used ,reduced from $\mathbf{5 . 3}$ (control salinity) to $3.9(\mathrm{dS} / \mathrm{m})$ in the area not provided with tile drainage which indicates a reduction in soil salinity about $26.4 \%$, while the reduction in soil salinity was about $47.2 \%$ in the area provided with tile drainage.

The amounts of leached salts from the soil depth 0-30 cm were 947.1 and 1059.9 $\mathrm{kg} / \mathrm{fed}$ for non- tiled and tiled areas of Mahllet Rooh area where fresh water is used for irrigation, respectively. On the other hand, these amounts of leached salts from the soil depth $30-60 \mathrm{~cm}$ below soil surface were 903.3 and $991.9 \mathrm{~kg} / \mathrm{fed}$, respectively. Concerning Saft Torab area, where mixed water is used for irrigation, these amounts were 673.9 and 1066.4 $\mathrm{kg} / \mathrm{fed}$ for the depth $0-30 \mathrm{~cm}$ and 548.2 and $898.7 \mathrm{~kg} / \mathrm{fed}$ for the depth $30-60 \mathrm{~cm}$ below soil surface for non- tiled and tiled drainage areas respectively. Figure (1) illustrates the amounts of leached salts removed from the top $60 \mathrm{~cm}$ of the soil for both areas under this study. 


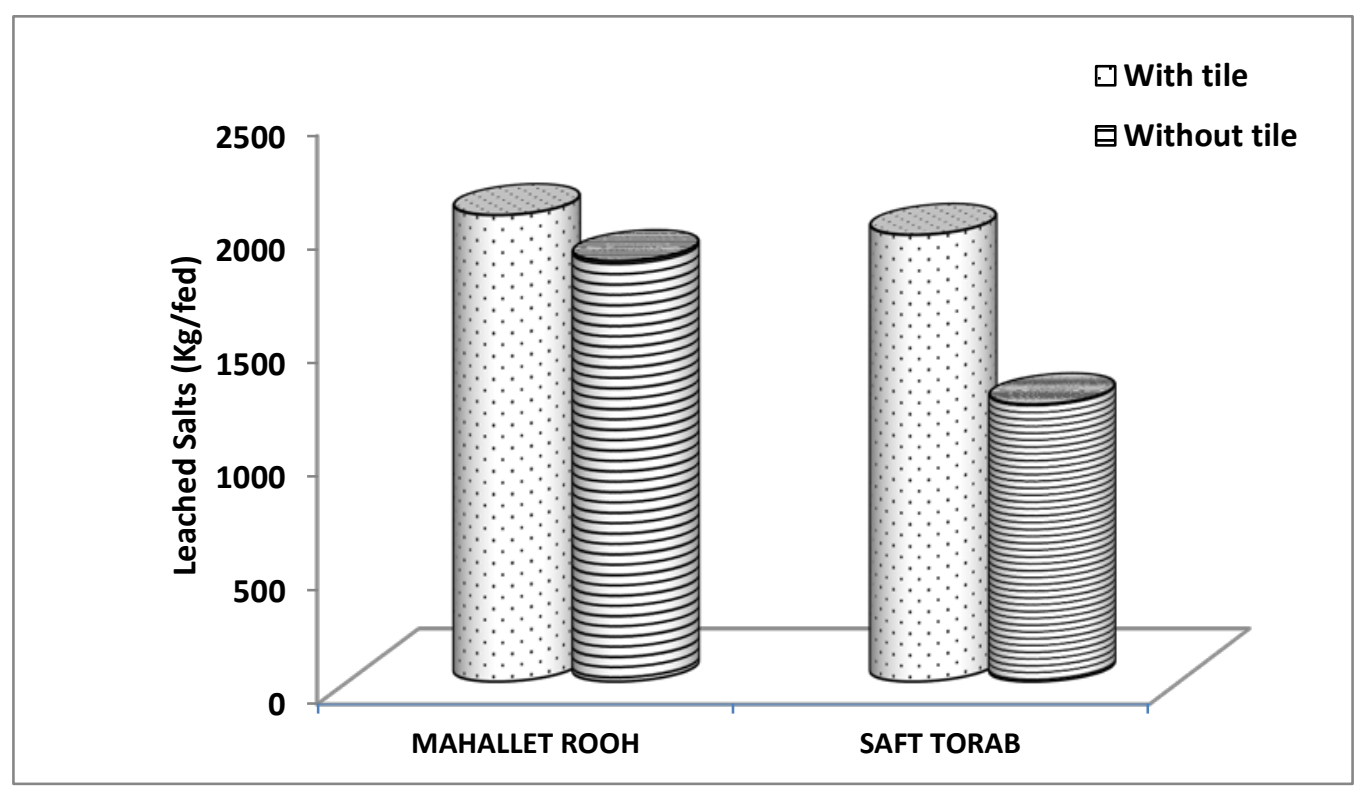

Fig. (1): Amounts of leached salts (kg/fed) for both areas under study.

\section{Effect of irrigation water quality} and drainage on some physical soil properties:

\subsection{Pore size distribution}

Pore size distribution of the top $60 \mathrm{~cm}$ soil layer in both studied areas was estimated from the pF curves. The results indicated differences between the studied areas and between the areas that have tile drainage system and that have not provided with tile drainage as shown in Figures (2 and 3).

Generally, it can be concluded from the obtained results (Fig. 2, 3, 4 and 5) and that, the tiled areas at Mahallet Rooh, where fresh irrigation water is applied, were relatively higher in quickly drainable pores QDP $(>28.8 \mu)$, slowly drainable pores SDP (28.8-8.62 $\mu$ ) and consequently the total drainable pores TDP $(>8.62 \mu)$ as compared to that of Saft Torab area where mixed water is used for irrigation (Fig. 4). On contrary, the water holding pores WHP $(8.62-0.19 \mu)$, fine capillary pores FCP $(<0.19 \mu)$ and coarse capillary pores CCP $(28.8-0.19 \mu)$ values were relatively higher as compared to that of Mahallet Rooh area. The non-tiled areas both in Mahallet
Rooh and Saft Torab showed almost the same values of pore size distribution components, except the fine capillary pores value (FCP) was slightly higher for Saft Torab as compared to Mahallet Rooh area (Fig. 5).

\subsection{Soil bulk density}

Soil bulk density values were estimated and illustrated in Fig. (6). The results indicated that soil bulk density values were lower in areas provided with tile drainage either in Mahallet Rooh or Saft Torab area resulting in higher total porosity values as compared to that not provided with tile drainage.

\section{Effect of irrigation water quality} and drainage on water table level and its salinity

Water table levels below soil surface were monitored and recorded during summer and winter seasons of this study, the data are illustrated in Fig. (7 and 8) for Mahallet Rooh area and Fig. (9 and 10) for Saft torab area. The results indicated that water table levels during winter season were much deeper than that observed in summer season in both studied areas. 
The tile drainage areas showed a pronounced effect on lowering water table level as compared to the areas that not provided with tile drainage system.

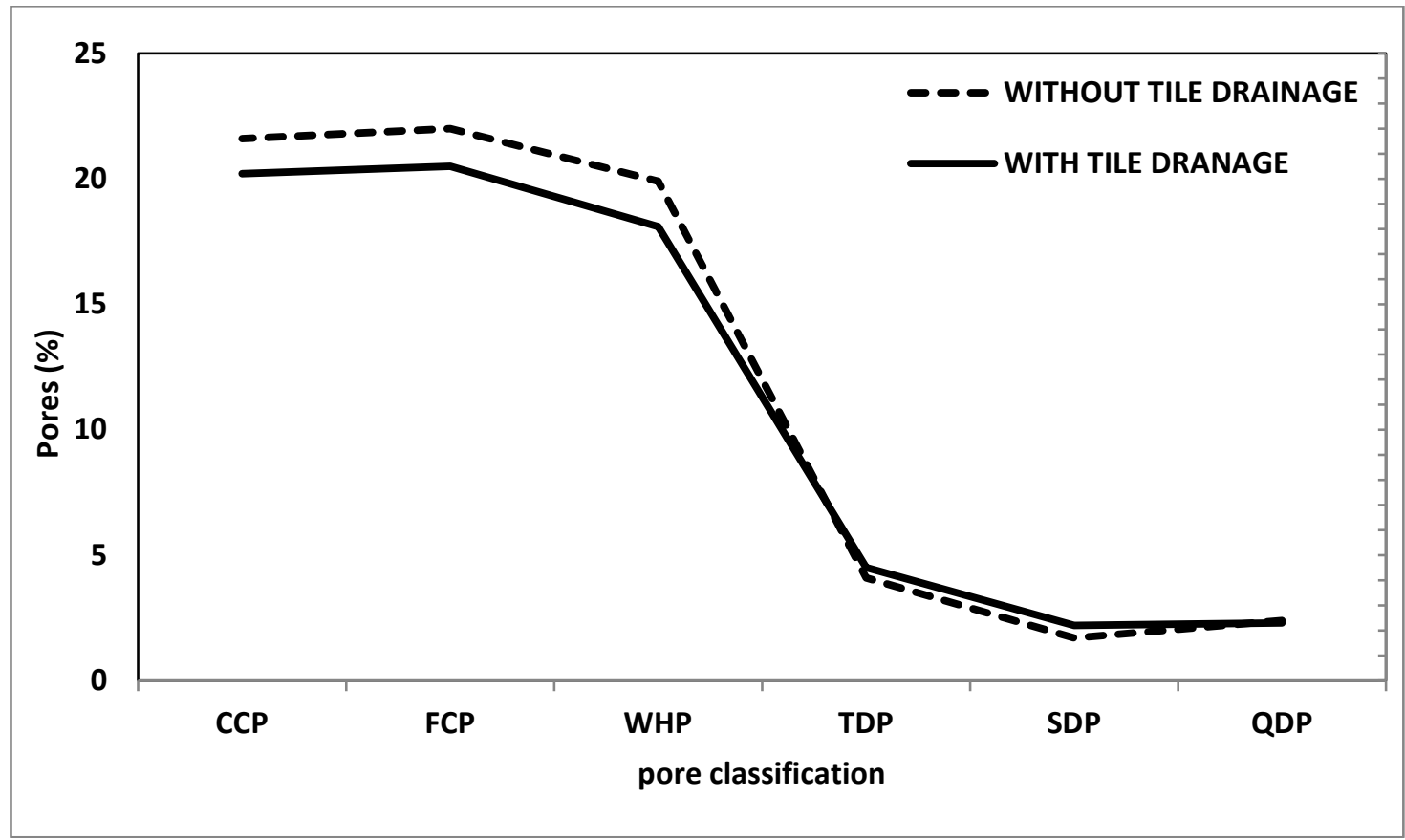

Fig. (2): Pore size distribution of Mahallet Rooh area for the top $60 \mathrm{~cm}$ of soil.

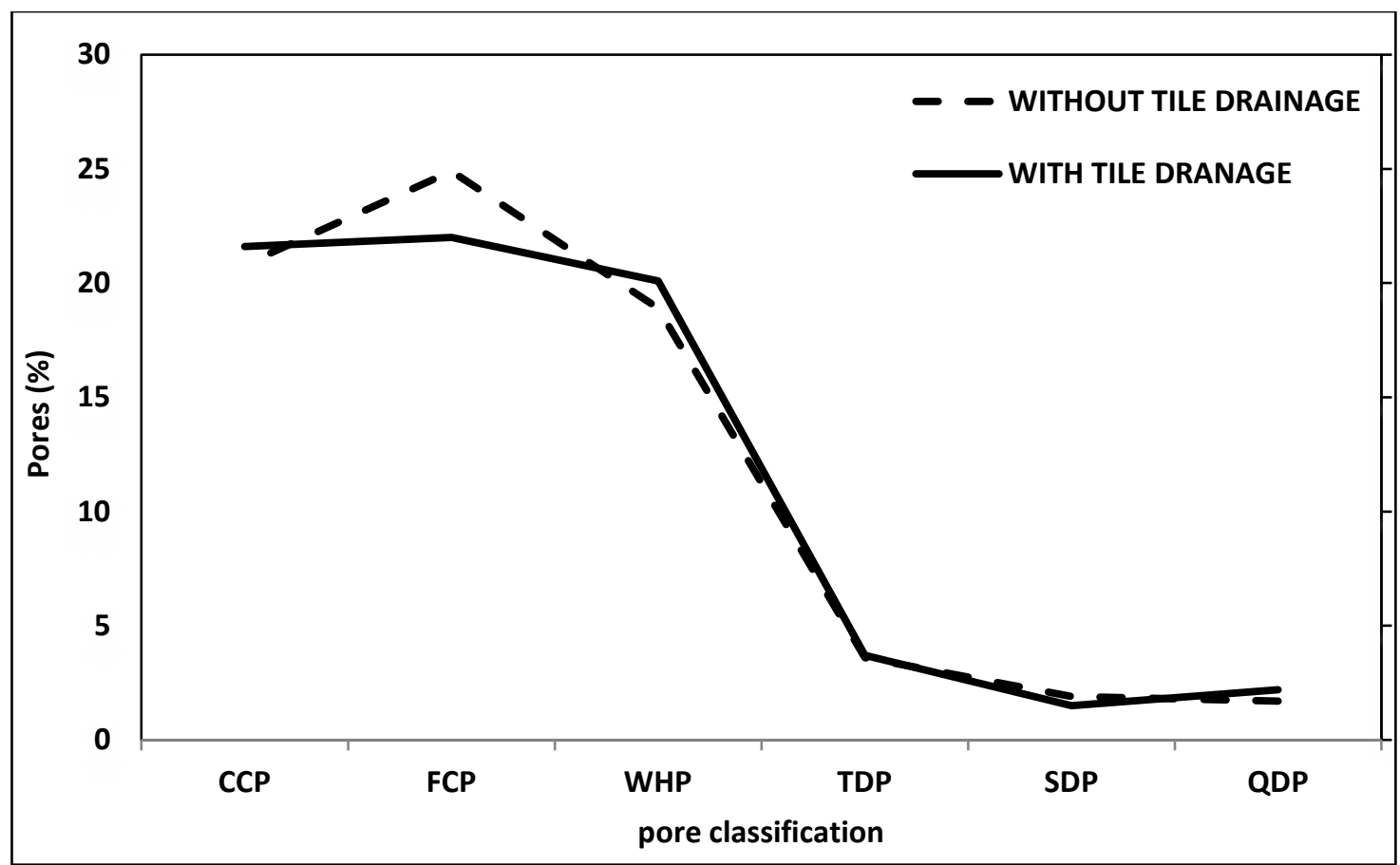

Fig. (3): Pore size distribution of Saft Torab area for the top $60 \mathrm{~cm}$ of soil. 


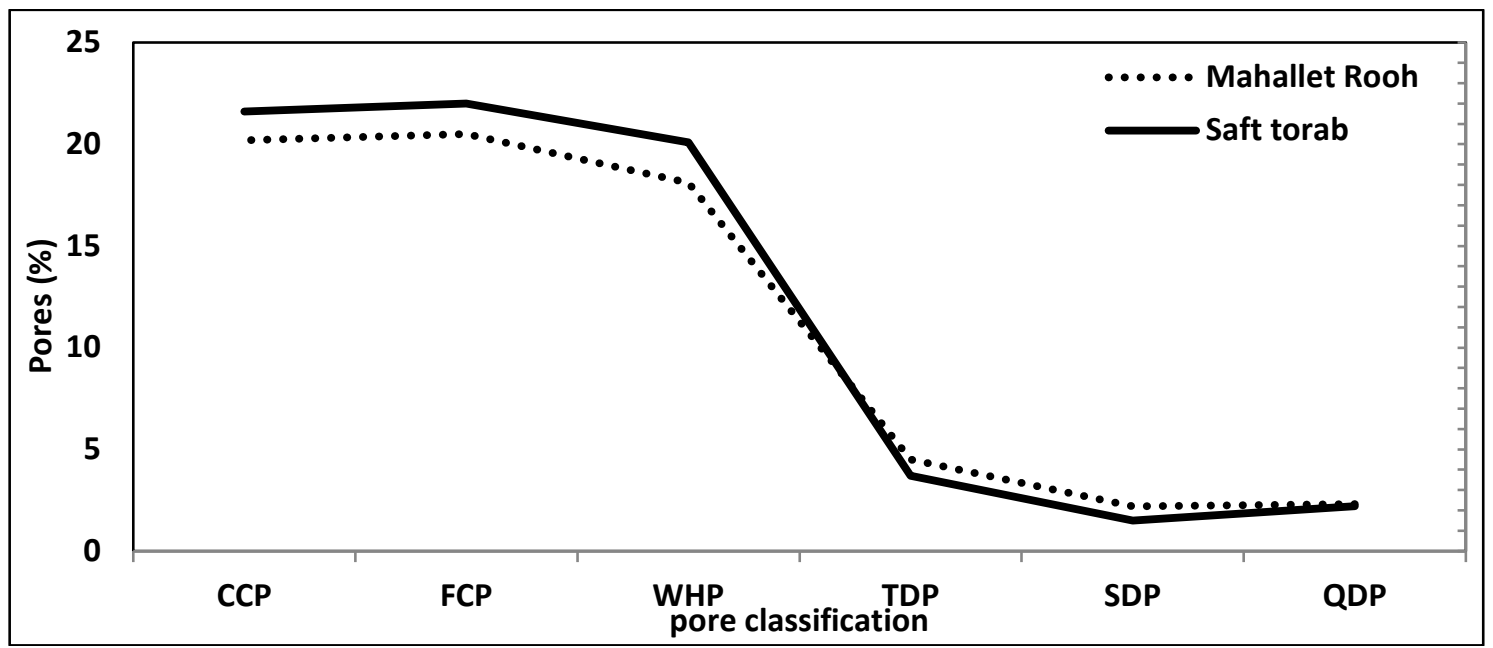

Fig. (4): Pore size distribution of tiled areas for top $60 \mathrm{~cm}$ of soil.

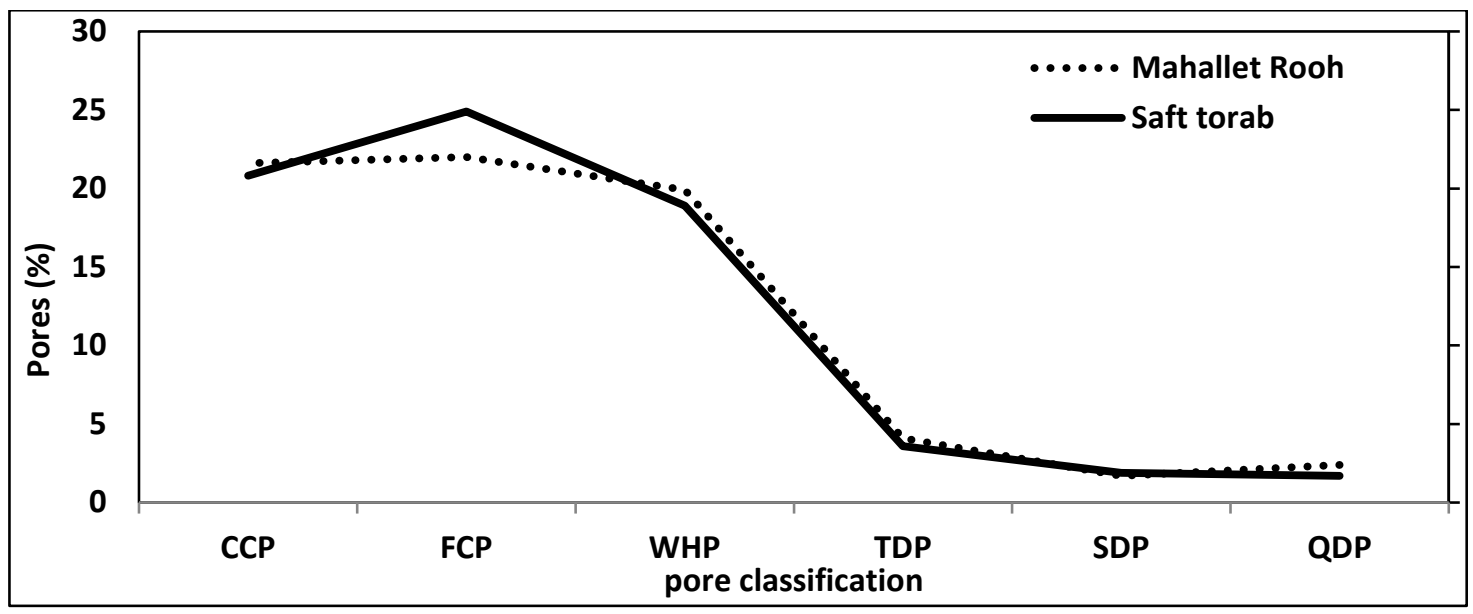

Fig. (5): Pore size distribution of non-tiled areas for top $60 \mathrm{~cm}$ of soil.

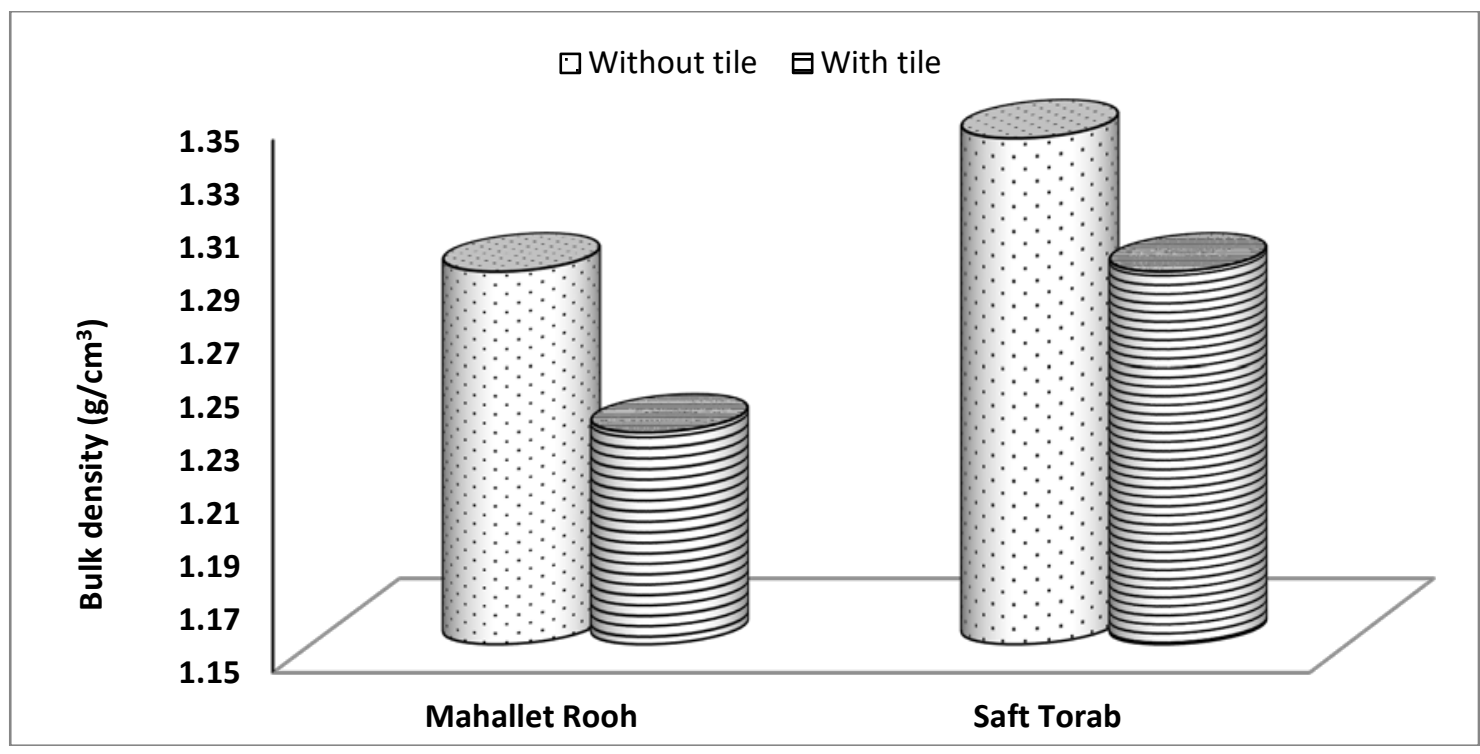

Fig. (6): Soil bulk density $\left(\mathrm{g} / \mathrm{cm}^{3}\right)$ for tiled and non-tiled areas. 


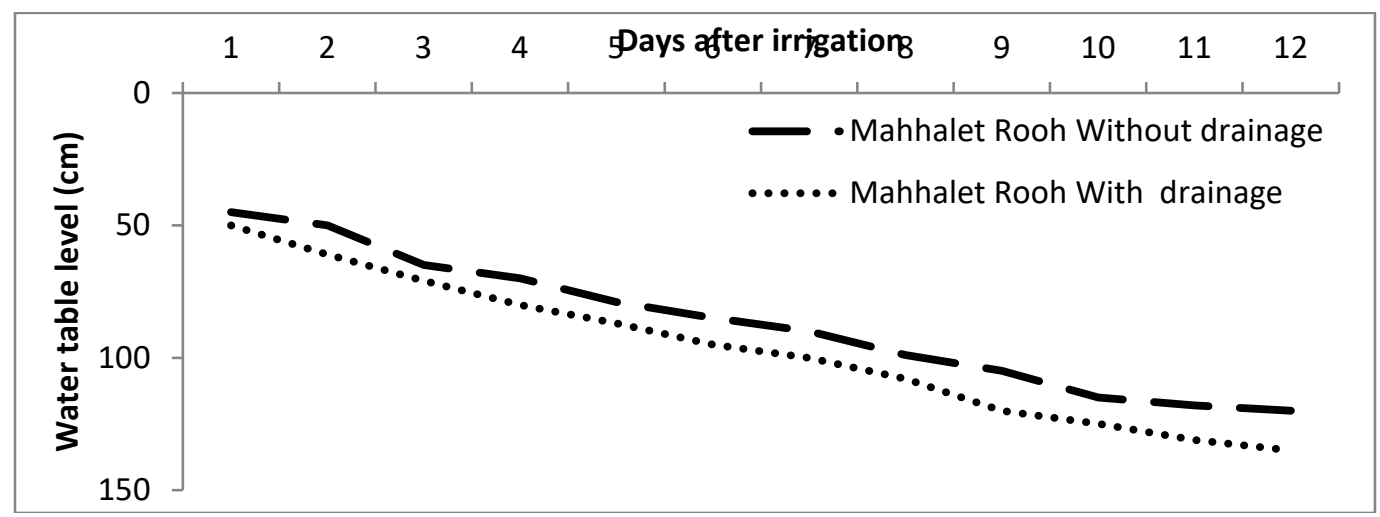

Fig. (7): Effect of tile drainage on water table level below soil surface at Mahallet Rooh area during winter season .

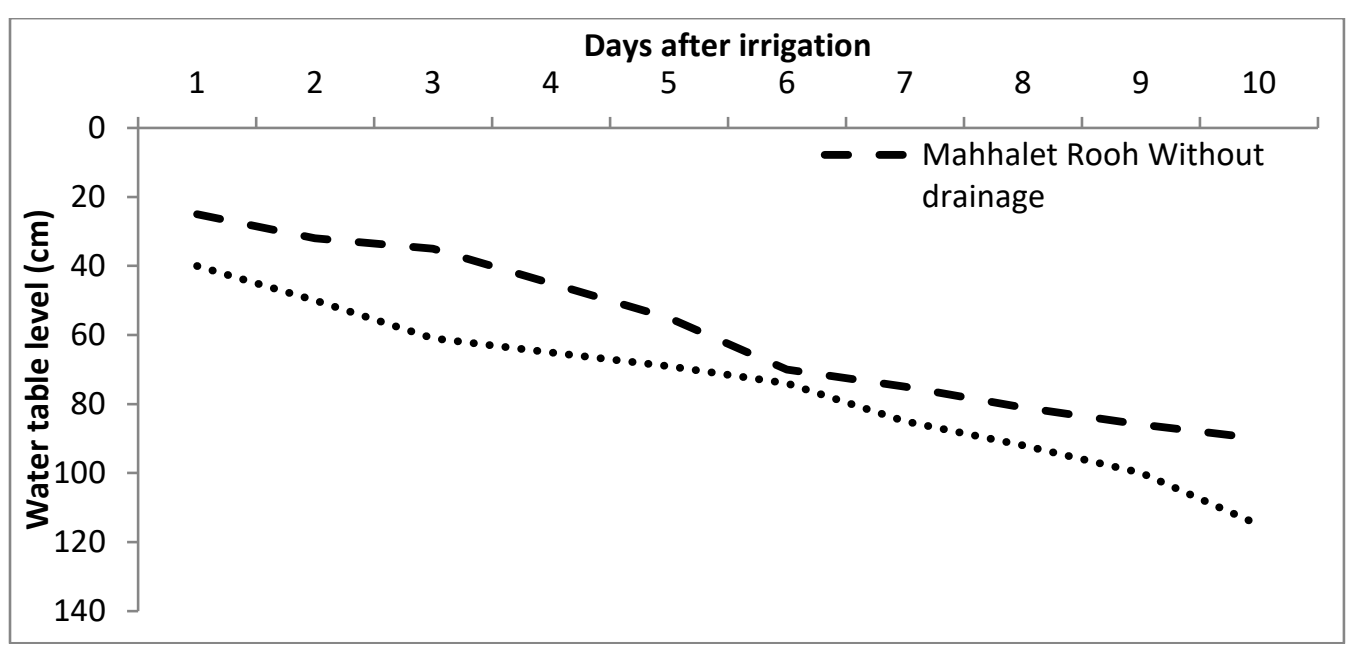

Fig. (8): Effect of tile drainage on water table level below soil surface at Mahallet Rooh area during summer season .

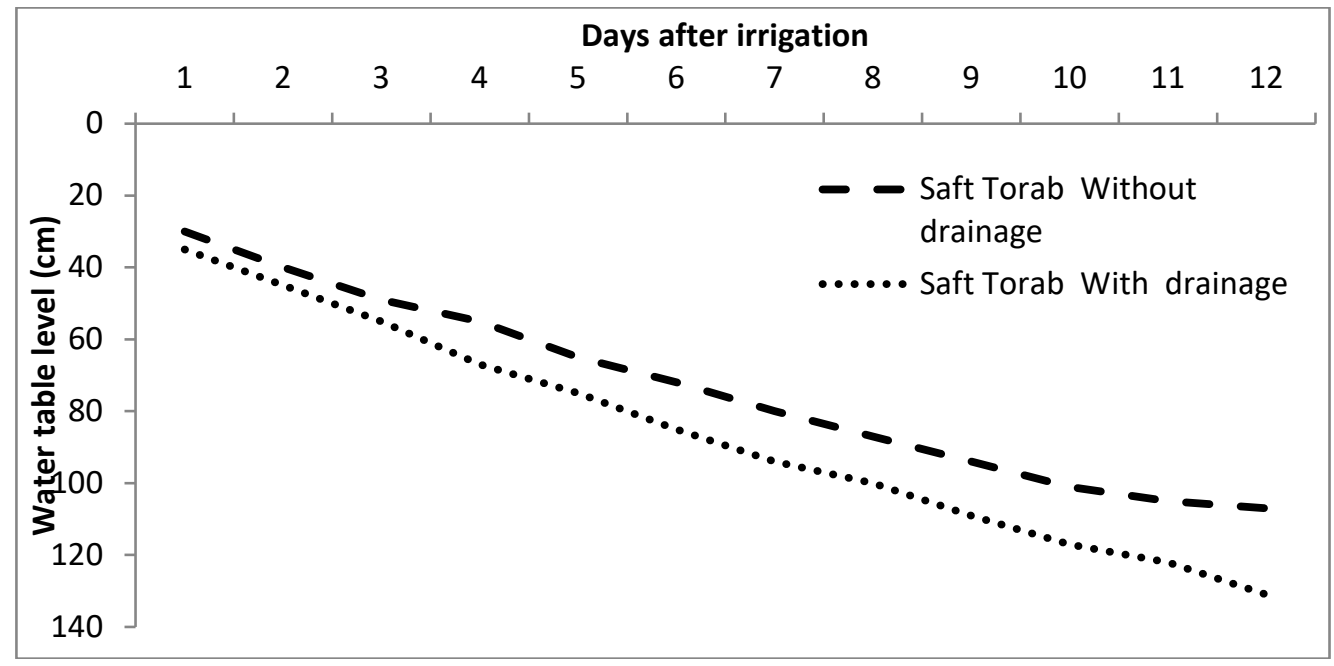

Fig. (9): Effect of tile drainage on water table level below soil surface at Saft Torab area during winter season . 


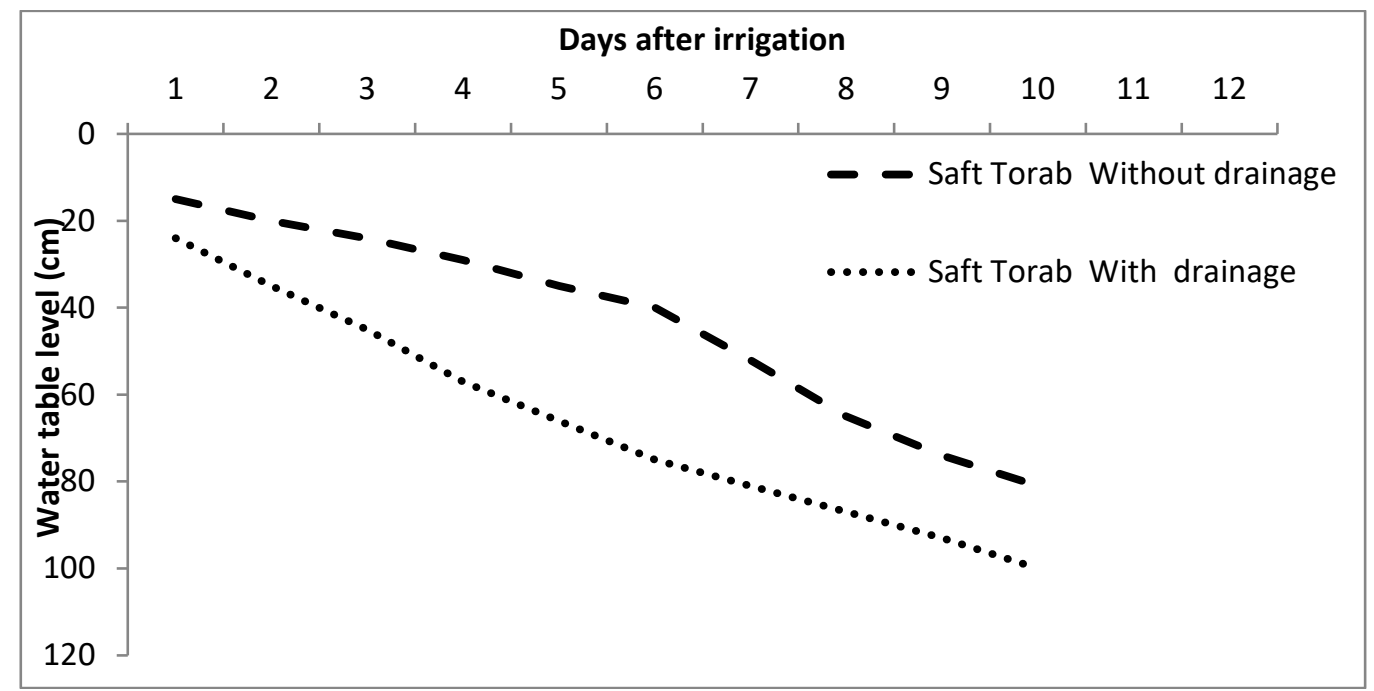

Fig. (10): Effect of tile drainage on water table level below soil surface at Saft Torab area during summer season .

Salinity of water table was estimated for both areas under the study. The results revealed that the average salinity of water table of Mahallet Rooh area where fresh irrigation water is used were $\mathbf{0 . 8 6}$ $\mathrm{dS} / \mathrm{m}$ and $0.75 \mathrm{dS} / \mathrm{m}$ for the areas non provided and provided with tile drainage, respectively. On the other hand, the average water table salinity values of Saft Torab where mixed irrigation water is used were higher than that observed in Mahallet Rooh area, these values were 1.85 and $1.24 \mathrm{dS} / \mathrm{m}$ for the area not provided tile drainage and that provided with tile drainage system,respectively. These results indicate that using mixed irrigation water, which has a relatively higher salt content, caused a higher salinity of water table as compared to that of Mahallet Rooh area where fresh irrigation water is used.

\section{Drain spacing evaluation according to actual field measurements}

To evaluate if the applied drain spacing fulfills the actual field conditions, drain spacing is calculated according to Hooghoudt equation using the field data measurements of soil hydraulic conductivity and water table levels midway between drains. The results revealed that using the field data the calculated drain spacing is $27 \mathrm{~m}$ at Mahallet Rooh area, while it was to $30 \mathrm{~m}$ spacing at Saft Torab. The designed values were $30 \mathrm{~m}$ which is almost the same as the calculated values. These results indicate to the good performance of tile drains in both areas under the study according to the field actual measurements.

\section{Effect of irrigation water quality and drainage on wheat and maize yields}

The effect of using fresh and mixed irrigation water in drained and nondrained areas under the study on both grain and biological wheat and maize yields are monitored. The results are illustrated in Figures (11 and 12) for wheat yield whereas; Figures (13 and 14) illustrated the results of maize yield.

The results revealed that in general, both grain and biological wheat and maize yields in drained areas and that irrigated with fresh water are higher than that obtained in non-drained areas and that irrigated with mixed water. 


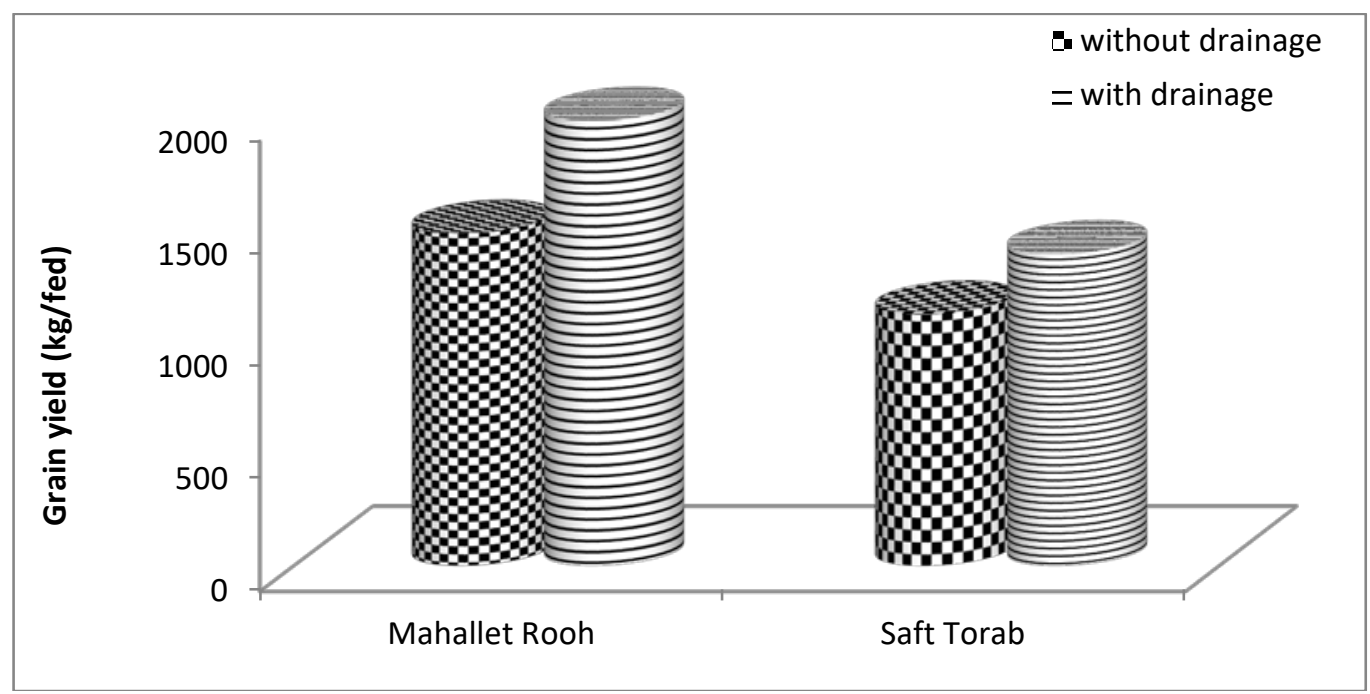

Fig. (11): Effect of tile drainage and irrigation water quality on wheat grain yield.

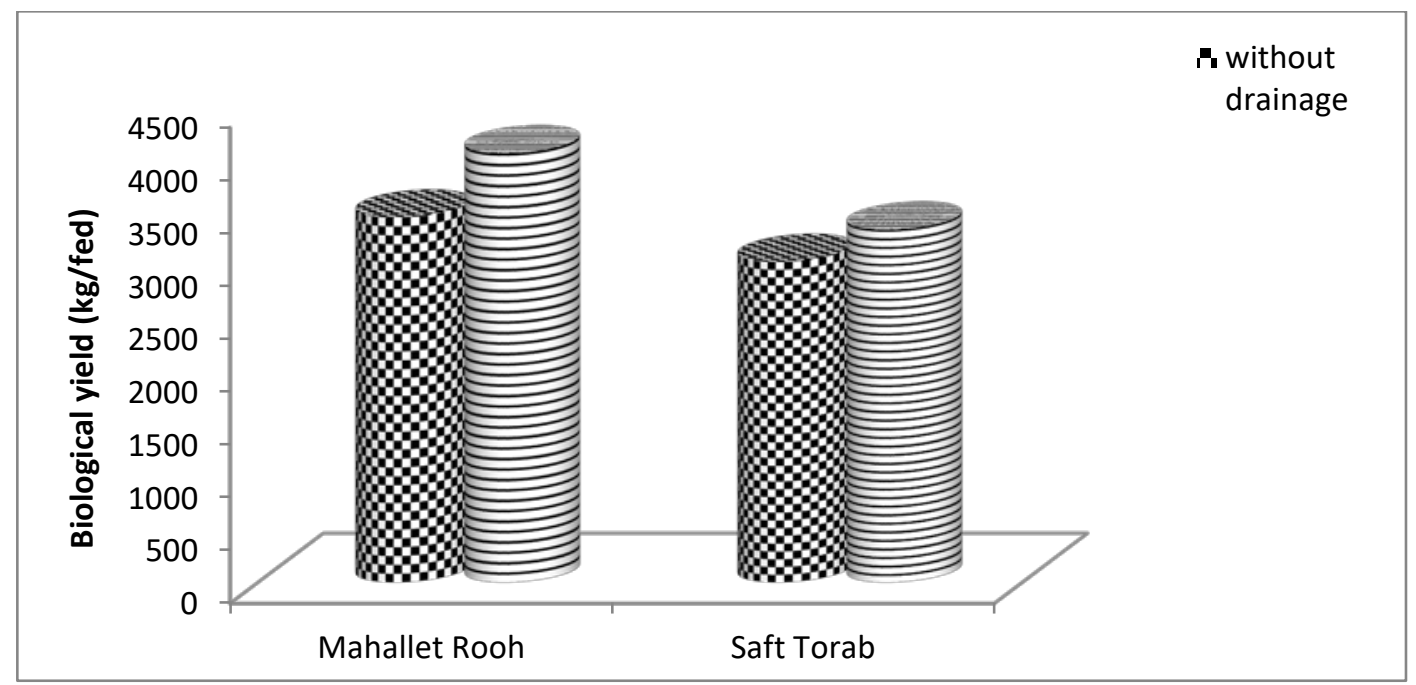

Fig. (12): Effect of tile drainage and irrigation water quality on biological yield of wheat.

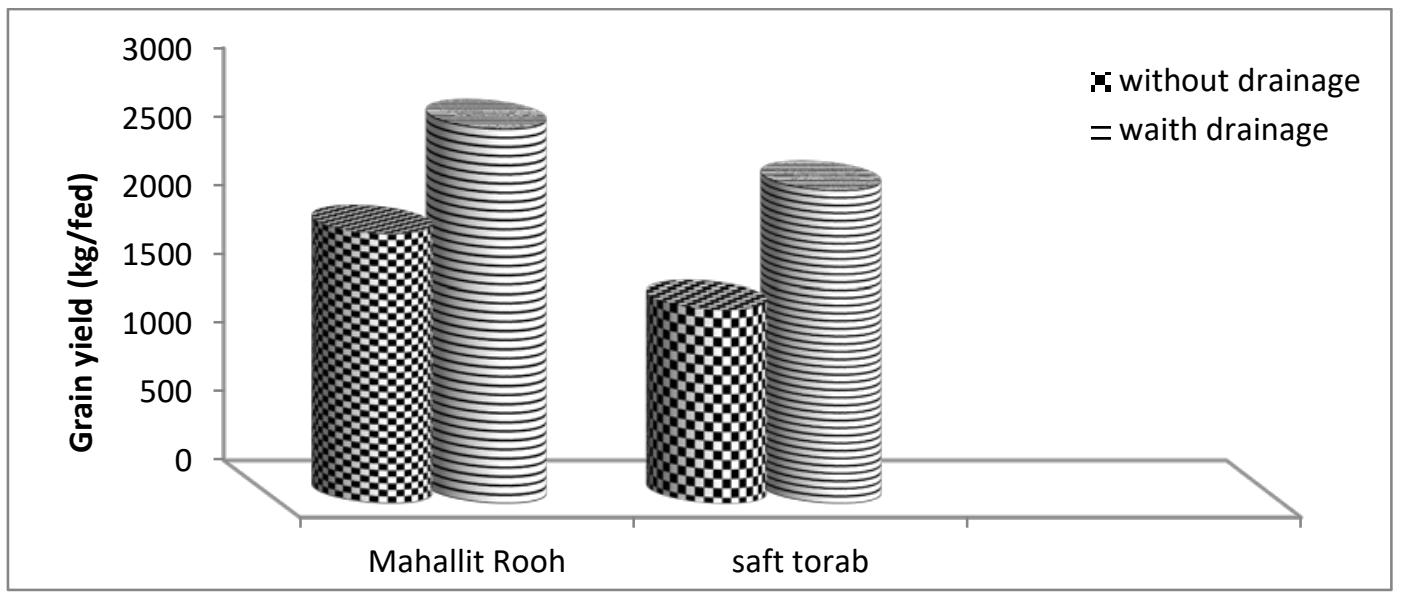

Fig. (13): Effect of tile drainage and irrigation water quality on maize grain yield. 


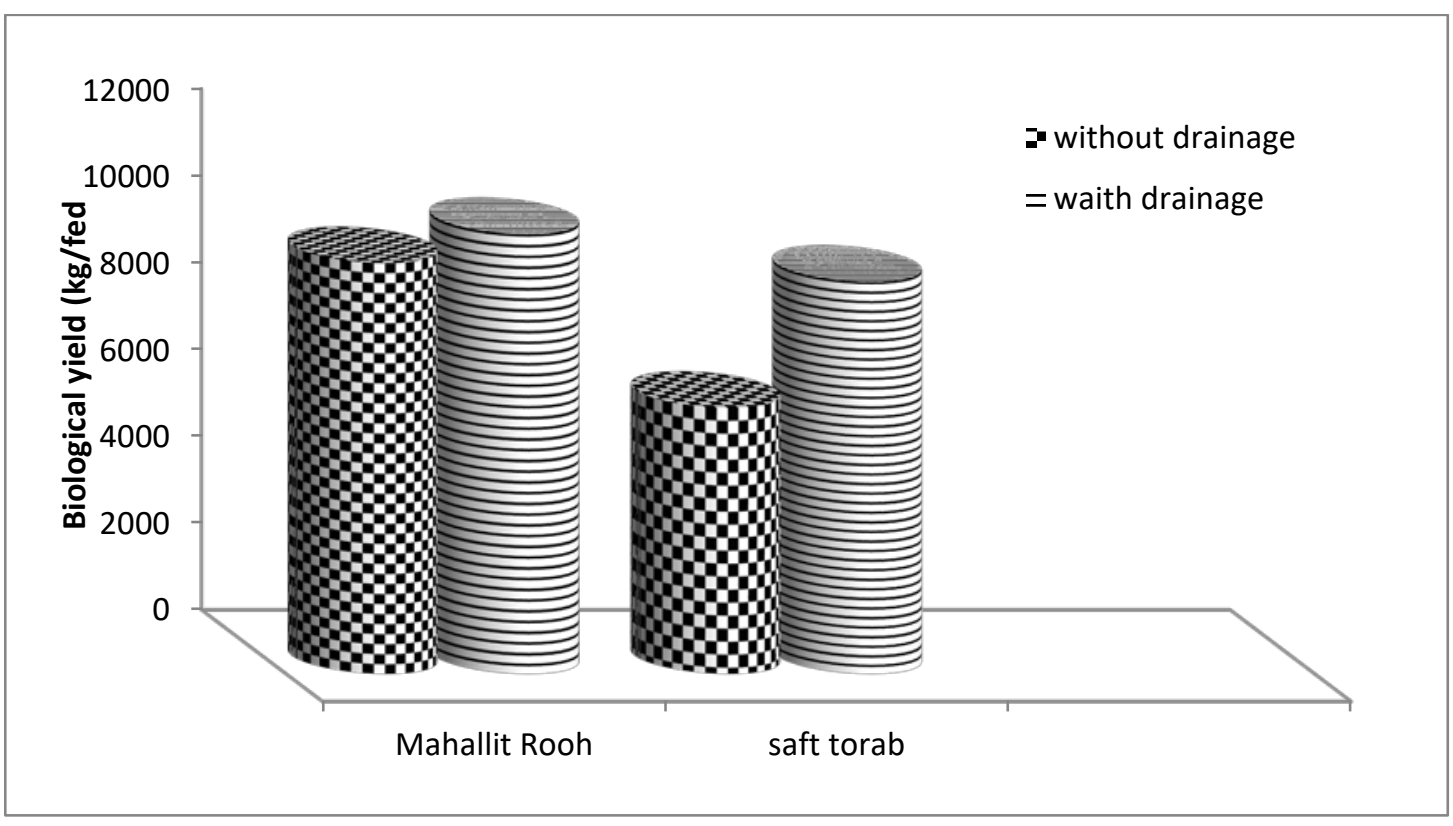

Fig. (14): Effect of tile drainage and irrigation water quality on biological yield of maize.

\section{REFERENCES}

Abdel Gawad, G. and A. Ghaibeh (2001). Use of low quality water for irrigation in the Middle East. Proc. Symp. Sustainable management of irrigated land for salinity and toxic elements control, US Salinity Laboratory Riverside, California,pp.20-25.

Abou El-Defan, T.A., S.A.A. El-Raies, H.M. El-Kholy and A.Sh.A. Osman (2016). A summary of water suitability criteria for irrigation. J.Soil Sci. and Agric. Eng., Mansoura Univ., 7(12): 981-989.

Ayers, R.S. and D.W. Westcot (1976). Water quality for Agriculture. FAO:29.

Bustan, A., M. Sagi, Y. De Malach and D. Pasternak (2004). Effects of saline irrigation water and heat waves on potato production in an arid environment. Field Crops Res. 90: 275285.

Chanduvi, F. (1997). Water management for salinity control. In: Proceedings of the Regional Workshop on Management of Salt Affected Soils in the Arab Gulf States, Abu Dhabi, UAE
29 October to 2 November 1995,FAO Regional Office for the North East, Cairo, pp. 63-65.

De Lennheer, L. and M. De Boodt (1965). Soil physics. Inter. Training Center for Post Graduate Soil Scientists, Gent.

Dieleman, P.J. and B.D. Trafford (1976). "Drainage Testing" Irrigation and Drainage. Paper No. 28. FAO, Rome, Italy. pp.78-81.

Doneen, L. D. (1964). Notes on water quality in agriculture. Davis, CA: Department of Water, Science, and Engineering. University of California.

Eaton, F.M. (1950). Significance of carbonates in irrigation waters. Soil Sci. 69: 123-133.

FAO (1994). Water Quality for Agriculture. Irrigation and Drainage Paper.. 29 Rev.2, FAO, Rome.

Ferreyra, R.E., A.U. Aljaro, R.S. Ruiz, L.P. Rojas and J.D. Oster (1997). Behavior of 42 crop species grown in saline soils with high boron concentrations. Agric. Water Manage. 34: 111-124. 
Genxiang, F., Z. Zhanyu, W. Changyu, L. Peirong and B. Ahmad (2017). Effects of saline water irrigation on soil salinity and yield of summer maize (Zea mays L.) in subsurface drainage system. Agricultural Water Management 193: 205-213.

Hamidreza, J.J., L. Abdolmajid, H. Alireza and $H$. Ritzema (2018). Managing controlled drainage in irrigated farmers' fields: A case study in the Moghan plain, Iran. Agricultural Water Management. 208: 393-405.

Hooghoudt, S.B. (1940). Bijdragen tot de kennis van enige natuurkundinge grootheden van de grond. No. 7 Versel Landbouwk. Onderz. 46: 515-707.

Jackson, M.L. (1967). Soil chemical analysis. Prentice Hall of India Ltd. New Delhi

Jessica, B. (2014). Mixing waters: The reuse of agricultural drainage water in Egypt. Geaforum. 57: 181-191.

Klute, A. (1986). Methods of soil analysis. Part 1.Physical and mineralogical methods $\left(2^{\text {nd }}\right.$ edition $)$ American Society of Agronomy Inc.,

Madison, Wisconsin, USA.

Mantell, A., H. Frenkel and A. Meiri (1985). Drip irrigation of cotton with salinesodic water. Irrig. Sci. 6: 95-106.

Minhas, P.S. (1996). Saline water management for irrigation in India. Agric. Water Manage. 35: 1-24.

Oster, J.D. (1994). Irrigation with poor quality water. Agric. Water Manag. 25: 271-297.

Page, A.L., R.H. Miller and D. R. Keeney (1982). "Methods of Soil Analysis". Part2: Chemical and microbiological properties, (2nd Ed.). Am.Soc. at Agron. Inc. Soil Sci. Soc. of Am. Inc., Madison, Wisconsin, VSA.

Pasternak, D., Y. De Malach and I. Borovic (1986). Irrigation with brackish water under desert conditions. VII. Effect of time of application of brackish water on production of processing tomatoes (Lycopersion esculentum Mill.). Agric. Water Manage.12: 149-158.

Pasternak, D. and Y. De Malach (1993). Crop irrigation with saline water. In: Pessarakli, Mohammad (Ed.), Handbook of Plant and Crop Stress. Marcel Dekker Inc., pp. 599-622.

Phogat, V., T. Pitta, J.W. Coxac, J. Šimůnekd and M.A. Skewesa (2018). Soil water and salinity dynamics under sprinkler irrigated almond exposed to a varied salinity stress at different growth stages. Agricultural Water Management. 201: 70-82.

Qadir, M., J.D. Oster, S. Schubert, A.D. Noble and K.L. Sahrawat (2007). Phytoremediation of Sodic and SalineSodic Soils. Advances in Agronomy.96, 197-247.

Rhoades, J.D., A. Kandiah and A.M. Mashali (1992). The Use of Saline Waters for Crop Production. FAO Irrigation and Drainage paper. FAO, United Nations, Rome, p. 48.

Rhoades, J.D. (1997). Strategies for the use of multiple water supplies for irrigation and crop production. In: Proceedings of the Regional Workshop on Management of Salt Affected Soils in the Arab Gulf States, Abu Dhabi, UAE October 29 to November 2, 1995, FAO regional office for the North East, Cairo, pp. 79-87.

Richards, L.A. (1954). Diagnosis and Improvement of saline and alkali soils. USDA Agricultural Handbook No. 60, US Department of Agriculture, Washington DC.

Shalhevet, J. (1994). Using water of marginal quality for crop production: major issues. Agric. Water Manage. 25: 233-269.

Shannon, M.C. and C.M. Grieve (1999). Tolerance of vegetable crops to salinity. Sci. Hort. 78: 5-38. 
Suarez, D.L. and I. Lebron (1993). Water quality criteria for irrigation with highly saline water. In: Lieth, H., Al Masoom, A. (Eds.), Towards the Rational Use of High Salinity Tolerant Plants, vol. 2. Kluwer Acadimic Publishers, pp. 389397.

Thomas, R.L., R. W. Shearel and Z. R. Mayer (1967). Comparison of conventional and automated procedure for nitrogen, phosphorus and potassium analysis of plant material using single digestion. Agron. J. 5: 240.

USSL (U.S. Salinity Lab.) staff (1954). Diagnosis and Improvement Saline and Alkaline Soil. Agric. Handbook 60.
Van Beers, W.F.J. (1976). The auger hole method. Bull. No. 1, ILRI, Wageningen, The Netherlands .

Wan, S., Y. Kang, D. Wang, S. Liu and L. Feng (2007). Effect of drip irrigation with saline water on tomato (Lycopersicon esculentum Mill) yield and water use in semi-humid area. Agric. Water Management (90): 63-74.

Wilcox, L.V. (1966). Tables of Calculating the pHc Values of Water. US Salinity Laboratory Mimeo Report.

Xiaobin Li (2018). Salt leaching and Iris germanica L. growth in two coastal saline soils under drip irrigation with saline water. Scientia Horticulturae . 234: 164-168. 
تأثثير الصرف المغطى ونوعية المياه المستخدمة فى الرى على بعض خواص التربة ومحصولى القمح والذرة

منى كمال مصطفى عبد الرازق ، مصطفى عبد العدل درويش ، حمدى عبد المنعم خفاجى

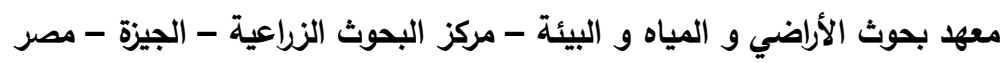

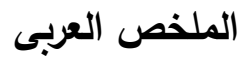
أجريت هذه الاراسة على مناطق ارض طينية طميية لمعرفة تأثير تنفيذ شبكة الصرف المغطى على مستوى الحقل مع

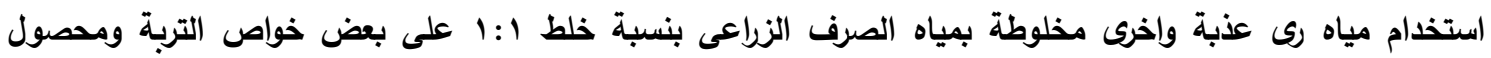

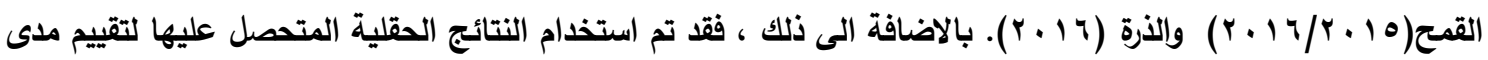
مطابقة المسافة بين الحقليات المنفذة فعليا ومقارنتها بالقيم المحسوبة من القياسات الحقلية وذلك بهذف معرفة مدى كفاءة

$$
\text { عمل شبكة الصرف الحقلية الموجودة . }
$$

ولاجراء هذه الاراسة تم اختيار منطقتى محلة روح وصفت تراب والتابعتين لمركز السنطة بمحافظة الغربية ، حيث يتم

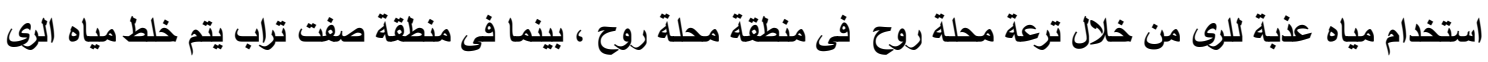

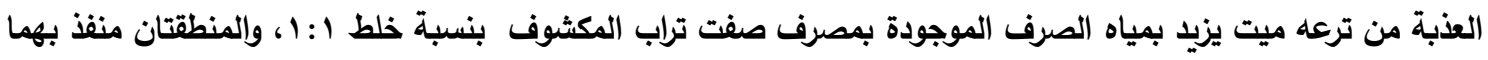

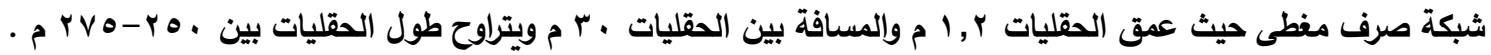
وقد تم اختيار ه أفدنة فى كل منطقة لاجراء الاراسة كما تم اختيار مساحة مماثلة بكلتا المنطقتين غير منفذ بها شبكة صرف مغطى للمقارنة. وقد اشارت النتائج المتحصل عليها من خلال التحليل الكيميائى لمياه الرى المستخدمة فى كلا المنطقتين أن كلا من المياه العذبة والمياه المخلوطة بمياه الصرف بنسبة 1:1 يمكن استخدامهما بأمان دون أى مشاكل تذكر طبقا للمعايير الاولية المتبعة فى تقييم صلاحية المياه للرى والتى تطبقها منظمة الاغذية والززاعة -الفاو (FAO,1994) وهذا يغنى انه

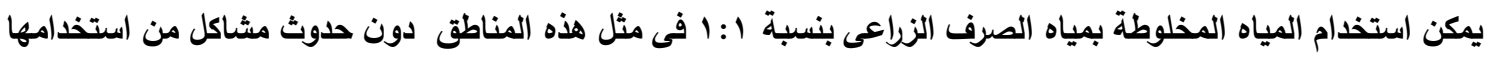

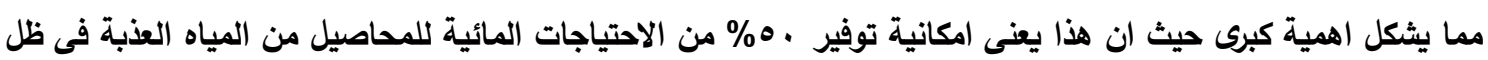

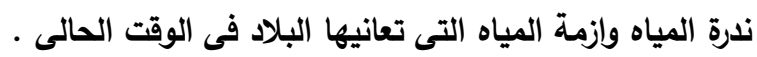
كما اثبتت النتائج ايضا انخفاض ملوحة|لتربة بنسبة v, . r\% فى منطقة محلة روح -وإلغير منف بها شبكة الصرف

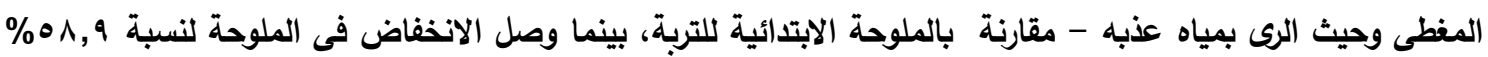
فى المنطقة المنفذ بها شبكة صرف مغطى بنفس المنطقة .

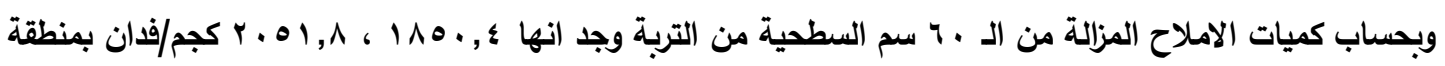

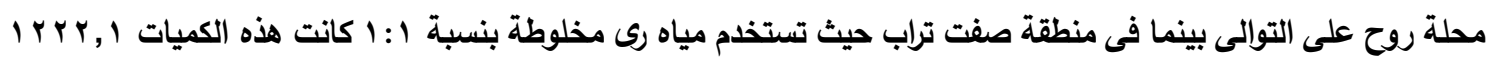

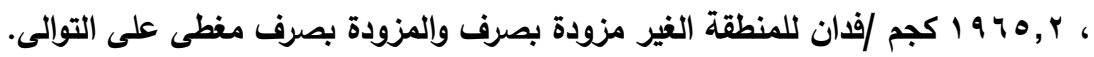

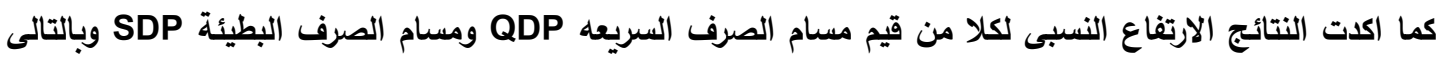

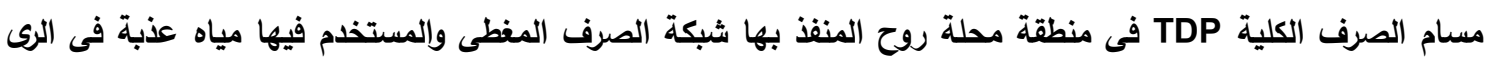

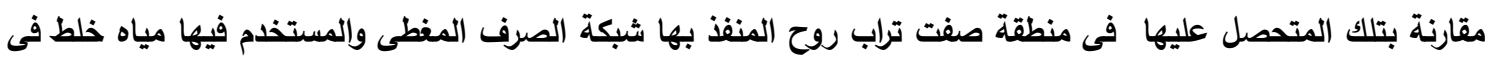

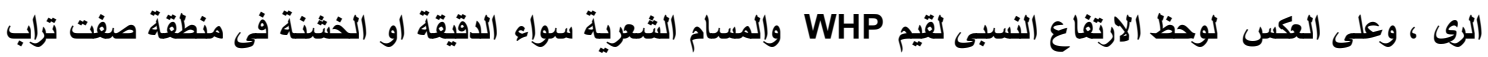


مقارنة بتلك المتحصل عليها بمنطقة محلة روح. كما لوحظ ان قيم التوزيع الحجمى للمسام فى المنطقتين الغير مزودتين

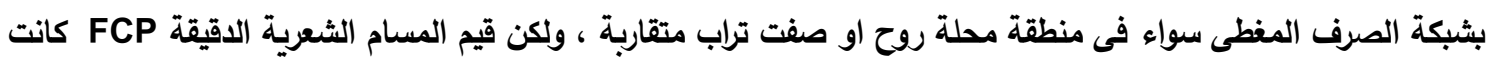

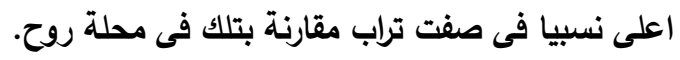

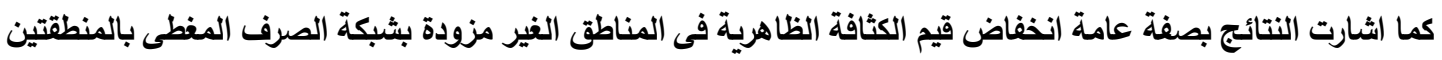
تحت الدراسة مقارنة بتلك المنفذ بها شبكة الصرف المغطى وذلك نتيجة ارتفاع المسامية الكلية.

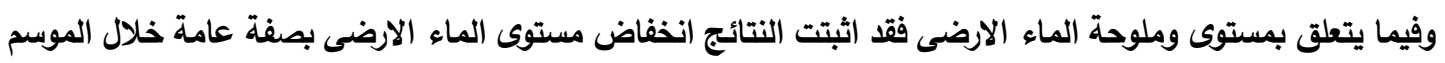

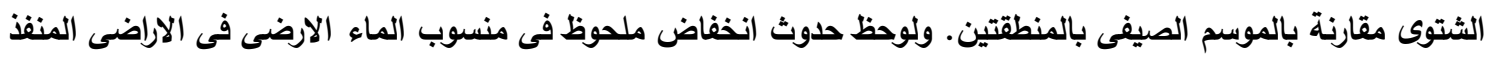
بها شبكة صرف مغطى مقارنة بتلك الغير منفذ بها ـ كما بينت النتائج ارتفاع ملوحة المياه الارضية نسبيا مع استخدام مياه باه الخلط. وقد تم استخدام القياسات الحقلية المتحصل عليها (نفاذية التربة - مستوى الماء الارضى فى منتصف المسافة بين

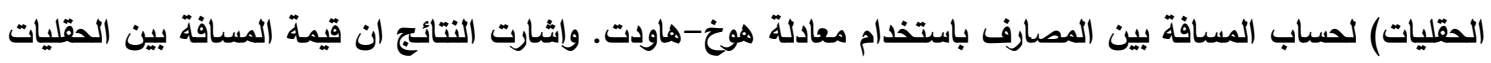

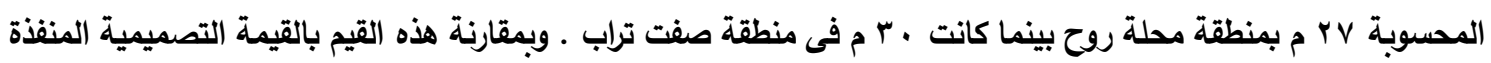

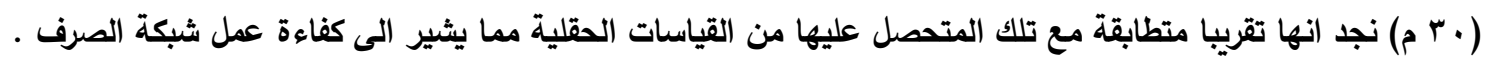
وقد اكلت النتائج ان انتاجية محصولي القمح والذرة كانت اعلى فى المناطق المزوده بثبكة الصرف المغطى والتى تروى بمياه عذبة مقارنة بتلك التى لم تزود بشبكة صرف مغطى او تروى دئ بمياه خلط. 